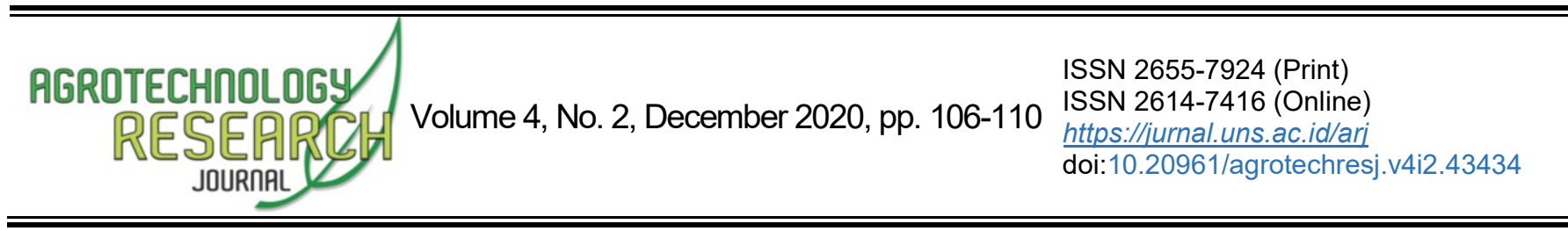

\title{
Potensi Ekstrak Kulit Buah Naga untuk Mitigasi Cekaman Salinitas pada Perkecambahan Benih Kedelai
}

\author{
Maman Suryaman ${ }^{1 *}$, Ida Hodiyah ${ }^{2}$, Neng Inten ${ }^{3}$ \\ ${ }^{1-3}$ Department of Agrotechnology, Faculty of Agriculture, Universitas Siliwangi, Tasikmalaya, Indonesia
}

Received 31 July 2020; Accepted 11 November 2020; Published 1 December 2020

\begin{abstract}
Salinity stress has negative effect on seed germination; therefore, it is necessary to find technology to mitigate it. The research was conducted to study the potency of peel extract of dragon fruit to mitigate salinity stress on soybean seed germination. This research used a randomized block design with factorial patterns and three replications. The first factor was the level of salinity of $\mathrm{NaCl}(\mathrm{C})$, consisted of 3 levels $\left(\mathrm{c}_{0}=0 \%, \mathrm{c}_{1}=0.5 \%, \mathrm{C}_{2}=1 \%\right)$, The second factor was peel extract of dragon fruit $(\mathrm{I})$, consisted of 3 levels ( $\mathrm{i}_{0}=0 \%$ (control), $\mathrm{i}_{1}=1 \%$, and $\mathrm{i}_{2}=2 \%$ ). The parameters analyzed were germination percentage, germination rate, root length, epicotyl length, electric conductivity, and dry weight of sprout. The data were analyzed with ANOVA and Duncan's multiple range test at $\alpha=5 \%$. The result showed no interaction between salinity stress and peel extract of dragon fruit on soybean seed germination. Salinity stress significantly decreased sprout vigor with the highest decrease was shown at $1 \%$ salinity; on contrarily peel extract of dragon fruit could maintain sprout vigor. Peel extract of dragon fruit $2 \%$ was the potential to mitigate salinity stress.
\end{abstract}

Keywords: Soybean; Abiotic stress; Sprout vigor; Viability

Cite This As (CSE Style): Suryaman M, Hodiyah I, Inten N. 2020. Potensi Ekstrak Kulit Buah Naga untuk Mitigasi Cekaman Salinitas pada Perkecambahan Benih Kedelai. Agrotech Res J. 4(2): 106-110. https://doi.org/10.20961/agrotechresj.v4i2.43434

\section{PENDAHULUAN}

Luas lahan pertanian di Indonesia mengalami tren penurunan yang signifikan, sehingga berdampak pada penurunan produksi hampir semua komoditas pertanian. Kondisi yang sama juga tergambarkan pada komoditas kacang kedelai yang merupakan salah satu sumber protein nabati penting. Tahun 2015 luas panen kedelai mencapai 614 ribu hektar, tahun 2016 turun menjadi 577 ribu hektar, bahkan pada tahun 2017 hanya mencapai 357 ribu hektar (Kementerian Pertanian 2017), sehingga berdampak terhadap penurunan produksi secara nasional. Kebutuhan kedelai terus meningkat dan tidak tercukupi dari produksi nasional sendiri, sehingga impor dilakukan. Impornya sendiri meningkat terus, dari tahun 2015 sebesar 6,417 juta ton, tahun 2016 sebesar 6,334 juta ton dan tahun pada 2017 mencapai 7,068 juta ton (Kementerian Pertanian 2018). Peningkatan produksi kedelai nasional dapat dilakukan diantaranya dengan cara ekstensifikasi atau perluasan areal tanam. Perluasan areal tanam kedelai dapat dilakukan baik pada lahan yang produktif maupun pada lahan yang marginal atau suboptimal. Lahan produktif sudah banyak yang beralih fungsi, maka penggunaan lahan

${ }^{*}$ Corresponding Author:

E-Mail: mamansuryaman@unsil.ac.id marginal/suboptimal menjadi pilihan. Salah satu lahan yang termasuk suboptimal adalah lahan yang mempunyai kadar garam tinggi (salin). Lahan salin dapat terbentuk karena terjadinya intrusi air laut, juga akibat tingkat evaporasi dan evapotranspirasi lebih besar dari curah hujan, serta akibat bahan induk tanahnya mengandung garam (Rachman et al. 2018).

Salinitas akan mempengaruhi seluruh proses pertumbuhan tanaman. Tanaman yang ditanam pada lahan yang mengalami cekaman salinitas akan mengalami cekaman osmotik, ketidakseimbangan hara, toksisitas ion, dan cekaman oksidatif (Sopandie 2013; Kristiono et al. 2018). Cekaman salinitas menyebabkan akumulasi Reactive Oxygen Species (ROS) yang berlebihan dalam sel, karena terganggunya proses transpor elektron dalam kloroplas, mitokondria dan membran plasma (Meloni et al. 2003). ROS termasuk kelompok radikal bebas, bersifat destruktif dan sangat reaktif karena memiliki elektron yang tidak berpasangan (Sayuti dan Yenrina 2015). Peningkatan jumlah ROS akan merusak biomolekul komponen pembentuk sel seperti lemak, protein dan DNA (Irianti et al. 2017). Selanjutnya terjadi perubahan sifat integritas membran, transpor ion, penurunan aktivitas enzim, hambatan sintesis protein, kerusakan DNA, yang berujung pada kematian sel (Sharma et al. 2012). Cekaman oksidatif menghambat pertumbuhan dan perkembangan dengan cara mengurangi perbanyakan sel, karena itu 
perlindungan pada fase perkecambahan benih sangatlah penting (Tabatabaei 2013).

Pada umumnya tanaman legum termasuk katagori sensitif terhadap cekaman salinitas (Khan dan Basha 2015), dengan ambang batas salinitas untuk kedelai sebesar 5,0 dS m-1 (identik dengan $5,0 \mathrm{mS} \mathrm{cm}^{-1}$ ) (Chinnusamy et al. 2005). Hingga saat ini masih terus dilakukan penelitian untuk mendapatkan varietas yang toleran terhadap salinitas. Penelitian baru sampai pada taraf memperoleh galur G1 (IAC100/Bur//Mal-10-KP-2150) dan galur G2 (Argopuro//IAC100) yang berpotensi untuk dikembangkan menjadi varietas unggul yang toleran terhadap salinitas (Purwaningrahayu dan Taufiq 2017).

Perkecambahan dan pertumbuhan bibit merupakan fase yang paling sensitif terhadap salinitas (Ibrahim 2016). Cekaman menghambat proses perkecambahan, mengurangi laju, dan meningkatkan heterogenitas perkecambahan sehingga menurunkan pertumbuhan dan hasil panen (Ansari dan Sharif-Zadeh 2012). Tanaman dapat melindungi diri dari kerusakan sel akibat ROS (radikal bebas) melalui sistem pertahanan antioksidan (Denaxa et al. 2020). Namun demikian, antioksidan endogen yang dihasilkan tanaman tidak cukup untuk mengatasi kerusakan akibat ROS (Soundararajan et al. 2019), oleh karena itu untuk mitigasi akibat cekaman perlu ditambahkan antioksidan secara eksogen.

Buah naga merupakan buah yang banyak digemari oleh masyarakat karena memiliki khasiat dan nilai gizi yang cukup tinggi. Pada umumnya setelah daging buahnya dikonsumsi, maka kulit buahnya dibuang, padahal di dalam kulitnya terkandung berbagai senyawa fitokimia yang bermanfaat. Sementara itu kulit buah naga dapat dimanfaatkan sebagai pewarna alami makanan, dibuat tepung dan sebagai sumber pektin (Handayani dan Rahmawati 2012; Rochmawati 2019; Jalgaonkar et al. 2020). Kulit buah naga mengandung total fenolik $28,16-36,12\left(\mathrm{mg}^{100 \mathrm{~g}^{-1}}\right)$, total vitamin C 0,0704-0,0762 (g $\left.1000 \mathrm{ml}^{-1}\right)$, betacianin 41,55 (mg g berat kering ${ }^{-1}$ ) (Jalgaonkar et al. 2020), flavonoid (QE) $0,59 \%$ (Tsai et al. 2019). Selain itu juga mengandung betalain (Thirugnanasambandham dan Sivakumar 2017), dan antosianin (Putri et al. 2015), semua senyawa atau zat tersebut termasuk kelompok antioksidan alami non enzimatik (Sayuti dan Yenrina 2015; Irianti et al. 2017). Sebagai suatu sistem pertahanan, kelompok antioksidan non enzimatik tersebut punya kemampuan untuk mendetoksifikasi ROS (Ahmad et al. 2019). Aktivitas antioksidan pada kulit buah lebih besar dibandingkan dengan daging buahnya (Nurliyana et al. 2010; Putri et al. 2015), berkaitan dengan kandungan total fenolik yang lebih tinggi pada kulit buah dibandingkan dengan yang terkandung dalam daging buahnya (Nurliyana et al. 2010; Jalgaonkar et al. 2020), sementara buah naga warna merah lebih tinggi aktivitas antioksidannya dibanding buah naga warna putih (Sekar et al. 2016). Oleh karena itu, ekstrak kulit buah naga berpotensi digunakan sebagai sumber antioksidan. Kebaharuan dari penelitian ini yakni upaya pemanfaatan ekstrak kulit buah naga sebagai sumber antioksidan dalam memitigasi dampak dari cekaman salinitas, sehingga proses pertumbuhan tanaman tetap berlangsung secara normal walaupun berada dalam lingkungan abiotik yang suboptimum. Penelitian ini bertujuan untuk mempelajari pengaruh interaksi antara ekstrak kulit buah naga dengan cekaman salinitas terhadap perkecambahan benih kedelai sehingga dapat diketahui potensi ekstrak kulit buah naga dalam memitigasi dampak cekaman salinitas.

\section{BAHAN DAN METODE}

Penelitian dilaksanakan pada bulan Februari tahun 2020, di Rumah Plastik dan Laboratorium Produksi Tanaman Fakultas Pertanian Universitas Siliwangi. Alat yang digunakan yaitu: conductivity meter dan $\mathrm{pH}$ meter. Bahan yang digunakan pada penelitian ini diantaranya benih kedelai varietas Anjasmoro, $\mathrm{NaCl}$ dan kulit buah naga warna merah.

Penelitian menggunakan Rancangan Acak Kelompok dengan pola faktorial. Faktor pertama yaitu cekaman salinitas (C) terdiri dari 3 taraf yaitu: $\mathrm{C}_{0}=\mathrm{NaCl} 0 \%$ (Air $=$ kontrol), $\mathrm{C}_{1}=\mathrm{NaCl} 0,5 \%\left(\mathrm{DHL}=7,87 \mathrm{mS} \mathrm{cm}^{-1}\right), \mathrm{C}_{2}=$ $\mathrm{NaCl} 1 \%\left(\mathrm{DHL}=9,98 \mathrm{mS} \mathrm{cm}^{-1}\right)$. Faktor kedua yaitu ekstrak kulit buah naga $(E)$ dengan 3 taraf yaitu : $e_{0}=$ ekstrak kulit buah naga $0 \%$ (air= kontrol), $\mathrm{e}_{1}=$ ekstrak kulit buah naga $1 \%, e_{2}=$ ekstrak kulit buah naga $2 \%$. Semua perlakuan diulang 3 kali. Ekstrak kulit buah naga dibuat dengan metode maserasi dengan menggunakan pelarut etanol $90 \%$, hingga diperoleh konsentrasi sesuai dengan perlakuan $(0 \%, 1 \%, 2 \%)$. Metode atau uji perkecambahan yang digunakan adalah uji di atas tanah.

Tanah sebagai media perkecambahan diayak lalu dihamparkan di atas baki perkecambahan selanjutnya disemprot dengan larutan $\mathrm{NaCl} 0 \%, 0,5 \%$, dan $1 \%$ sampai kondisi lembap sesuai dengan perlakuan salinitas. Sementara itu, benih kedelai direndam dalam larutan ekstrak kulit buah naga $(0 \%, 1 \%, 2 \%)$ sesuai dengan perlakuan selama 12 jam, lalu dibilas dengan air, ditiriskan selanjutnya ditanam. Kondisi kelembaban media perkecambahan terus dipelihara dengan cara menambahkan larutan $\mathrm{NaCl}(0 \%, 0,5 \%, 1 \%)$ hingga lembap sampai percobaan berakhir (sampai 8 hari).

Parameter yang diamati terdiri dari : daya kecambah, kecepatan perkecambahan, panjang epikotil, panjang akar, bobot kering kecambah, dan daya hantar listrik kecambah. Data dianalisis dengan ANOVA dan dilanjutkan dengan uji jarak berganda Duncan dengan a $=5 \%$.

\section{HASIL DAN PEMBAHASAN}

Peningkatan cekaman salinitas dari $\mathrm{NaCl} 0 \%$ ke $\mathrm{NaCl} 1 \%$ diikuti dengan penurunan daya kecambah dan laju perkecambahan secara signifikan, sedangkan pemberian ekstrak kulit buah naga memberikan pengaruh yang sebaliknya (Tabel 1). Semakin meningkatnya cekaman salinitas, maka akan berdampak semakin rendah daya kecambah dan semakin lambat laju perkecambahannya. Cekaman salinitas $\mathrm{NaCl} 1 \%$ menurunkan daya kecambah sebesar $24,5 \%$ dari $83,89 \%$ (tanpa cekaman) menjadi $63,33 \%$ dan mengurangi kecepatan perkecambahan sebesar $11,5 \%$ dari $8,50 \%$ etmal $^{-1}$ (tanpa cekaman) menjadi $7,62 \%$ etmal $^{-1}$. Meningkatnya cekaman salinitas pada 
umumnya akan berdampak semakin berkurangnya serapan air akibat meningkatnya cekaman osmotik di lingkungan sekitar perakaran, sehingga proses perkecambahan dan laju perkecambahan akan mengalami hambatan. Kondisi tersebut sejalan dengan pendapat (Ahmed et al. 2016) bahwa salinitas mempengaruhi tanaman melalui efek osmotik dan toksisitas ion, yang akan mempengaruhi terhadap proses pertumbuhan.

Tabel 1. Pengaruh cekaman salinitas terhadap daya kecambah dan laju perkecambahan kedelai yang diberi ekstrak kulit buah naga

\begin{tabular}{lcc}
\hline Perlakuan & $\begin{array}{c}\text { Daya } \\
\text { kecambah } \\
(\%)\end{array}$ & $\begin{array}{c}\text { Laju } \\
\text { perkecambahan } \\
\left(\% \text { etmal }{ }^{-1}\right)\end{array}$ \\
\hline $\mathrm{NaCl} \mathrm{0} \mathrm{\%} \mathrm{(kontrol)}$ & $83,89 \mathrm{c}$ & $8,50 \mathrm{~b}$ \\
$\mathrm{NaCl} \mathrm{0,5 \%}$ & $76,11 \mathrm{~b}$ & $7,70 \mathrm{a}$ \\
$\mathrm{NaCl} \mathrm{1 \%}$ & $63,33 \mathrm{a}$ & $7,62 \mathrm{a}$ \\
\hline $\begin{array}{l}\text { Ekstrak kulit buah } \\
\text { naga 0 \% (kontrol) }\end{array}$ & $71,67 \mathrm{a}$ & $7,54 \mathrm{a}$ \\
$\begin{array}{l}\text { Ekstrak kulit buah } \\
\text { naga 1 \% }\end{array}$ & $75,56 \mathrm{a}$ & $8,21 \mathrm{~b}$ \\
$\begin{array}{l}\text { Ekstrak kulit buah } \\
\text { naga 2 \% }\end{array}$ & $76,11 \mathrm{a}$ & $8,06 \mathrm{~b}$ \\
\hline
\end{tabular}

Keterangan: Angka rata-rata yang ditandai dengan huruf yang sama pada kolom yang sama menunjukkan tidak berbeda nyata menurut Uji Jarak Berganda Duncan pada taraf $\alpha 0,05$.

Tabel 2. Pengaruh cekaman salinitas terhadap panjang epikotil, dan panjang akar kedelai yang diberi ekstrak kulit buah naga

\begin{tabular}{lcc}
\hline Perlakuan & $\begin{array}{c}\text { Panjang } \\
\text { epikotil } \\
(\mathrm{cm})\end{array}$ & $\begin{array}{c}\text { Panjang } \\
\text { akar } \\
(\mathrm{cm})\end{array}$ \\
\hline $\mathrm{NaCl} \mathrm{0} \mathrm{\%} \mathrm{(kontrol)}$ & $8,02 \mathrm{c}$ & $14,60 \mathrm{~b}$ \\
$\mathrm{NaCl} 0,5 \%$ & $7,08 \mathrm{~b}$ & $12,28 \mathrm{a}$ \\
$\mathrm{NaCl} \mathrm{1 \%}$ & $5,97 \mathrm{a}$ & $11,20 \mathrm{a}$ \\
\hline Ekstrak kulit buah naga 0 \% & $6,60 \mathrm{a}$ & $11,50 \mathrm{a}$ \\
(kontrol) & $6,94 \mathrm{a}$ & $12,59 \mathrm{ab}$ \\
Ekstrak kulit buah naga 1\% & $7,53 \mathrm{a}$ & $13,99 \mathrm{~b}$ \\
\hline Ekstrak kulit buah naga 2\%
\end{tabular}

Keterangan: Angka rata-rata yang ditandai dengan huruf yang sama pada kolom yang sama menunjukkan tidak berbeda nyata menurut Uji Jarak Berganda Duncan pada taraf a 0,05.

Sementara itu, pemberian ekstrak kulit buah naga tidak meningkatkan daya kecambah secara nyata dibandingkan perlakuan lainnya, namun meningkatkan kecepatan perkecambahan secara nyata. Peningkatan kecepatan perkecambahan akibat pemberian ekstrak kulit buah naga berkisar dari 6,9\% hingga 8,9\% dibandingkan tanpa pemberian ekstrak kulit buah naga. Efek positif dari ekstrak kulit buah naga dalam meningkatkan laju perkecambahan, diduga karena mengandung senyawa bioaktif yang bersifat antioksidan sehingga dapat menangkal dampak dari cekaman oksidatif (Fidrianny et al. 2017).
Peningkatan cekaman salinitas dari $\mathrm{NaCl} 0 \%$ ke $\mathrm{NaCl} 1 \%$ berdampak mengurangi panjang epikotil dan panjang akar secara signifikan, sedangkan pemberian ekstrak kulit buah naga memberikan pengaruh terhadap penambahan panjang epikotil dan panjang akar (Tabel 2). Tingkat cekaman salinitas yang semakin tinggi menyebabkan penghambatan pertumbuhan yang semakin tinggi, seperti tercermin dari penurunan panjang epikotil dan panjang akar. Cekaman salinitas $\mathrm{NaCl} 0,5 \%$ mereduksi panjang epikotil sebesar $12 \%$, dan cekaman salinitas $\mathrm{NaCl} 1 \%$ mengurangi panjang sebesar $25 \%$. Sementara itu perlakuan cekaman salinitas mereduksi panjang akar berkisar dari $16 \%$ hingga $23 \%$ dibandingkan dengan kontrol. Konsentrasi $\mathrm{NaCl}$ yang tinggi di dalam tanah menyebabkan berbagai efek negatif terhadap pertumbuhan dan perkembangan tanaman. Peningkatan pelarutan $\mathrm{NaCl}$ di zona perakaran dapat menimbulkan cekaman osmotik, serta akumulasi ion $\mathrm{Na}^{+}$dan $\mathrm{Cl}^{-}$di dalam tanah dapat menimbulkan keracunan bagi sel tanaman (Sopandie 2013; Jungklang 2018), yang akan menghambat proses pertumbuhan sehingga berdampak terhadap penurunan panjang epikotil dan panjang akar. Penggunaan ekstrak kulit buah naga memberikan efek positif berupa penambahan panjang epikotil dan panjang akar. Panjang epikotil bertambah secara tidak nyata, sedangkan terhadap panjang akar berpengaruh meningkatkan secara nyata akibat pemberian ekstrak kulit buah naga. Pemberian ekstrak kulit buah naga secara bertingkat dari $0 \%$ hingga $1 \%$ meningkatkan panjang akar dari $11,50 \mathrm{~cm}$ menjadi $13,99 \mathrm{~cm}$ secara nyata. Banyak peneliti yang mendapatkan bukti bahwa kulit buah naga mengandung sejumlah senyawa bioaktif yang bersifat antioksidan (Putri et al. 2015; Fidrianny et al. 2017), seperti fenolik, vitamin C, betacianin (Jalgaonkar et al. 2020), flavonoid (Tsai et al. 2019), yang mampu meredam radikal bebas yang berasal dari sel yang mengalami cekaman (Sayuti dan Yenrina 2015), sehingga proses pertumbuhannya tidak mengalami gangguan.

Peningkatan cekaman salinitas dari $\mathrm{NaCl} 0 \%$ ke $\mathrm{NaCl} 1 \%$ berdampak meningkatkan daya hantar listrik dan mereduksi bobot kering kecambah secara signifikan, sedangkan pemberian ekstrak kulit buah naga memberikan pengaruh yang sebaliknya juga secara signifikan (Tabel 3). Makin meningkat cekaman salinitas, makin besar daya hantar listriknya, serta makin mereduksi bobot kering. Perlakuan cekaman salinitas $1 \% \mathrm{NaCl}$ menyebabkan peningkatan daya hantar listrik sebesar $162 \%$ dan mengurangi bobot kering kecambah sebanyak $37 \%$ dibandingkan dengan tanpa cekaman. Peningkatan daya hantar listrik menggambarkan tingkat kebocoran membran sel dari kecambah tersebut yang semakin lanjut. Salinitas meningkatkan jumlah ROS yang dapat merusak biomolekul seperti lemak, protein dan DNA, selanjutnya berdampak terhadap perubahan sifat integritas membran (Sharma et al. 2012) sehingga meningkatkan kebocoran membran. Selain itu, cekaman salinitas akan mengurangi serapan air sehingga akan menghambat proses perkecambahan dan pertumbuhan yang selanjutnya berakibat berkurangnya akumulasi bahan kering. 
Tabel 3. Pengaruh cekaman salinitas terhadap daya hantar listrik dan bobot kering kecambah kedelai yang diberi ekstrak kulit buah naga

\begin{tabular}{lcc}
\hline Perlakuan & $\begin{array}{c}\text { Daya hantar } \\
\text { listrik } \\
\left(\mathrm{mS} \mathrm{cm}^{-1}\right)\end{array}$ & $\begin{array}{c}\text { Bobot kering } \\
(\mathrm{g})\end{array}$ \\
\hline $\mathrm{NaCl} \mathrm{0 \%} \mathrm{(kontrol)}$ & $8,95 \mathrm{a}$ & $0,08 \mathrm{~b}$ \\
$\mathrm{NaCl} \mathrm{0,5 \%}$ & $17,08 \mathrm{~b}$ & $0,06 \mathrm{a}$ \\
$\mathrm{NaCl} \mathrm{1 \%}$ & $23,47 \mathrm{c}$ & $0,05 \mathrm{a}$ \\
\hline Ekstrak kulit buah naga & $18,09 \mathrm{~b}$ & $0,05 \mathrm{a}$ \\
$0 \%$ (kontrol) & & \\
Ekstrak kulit buah naga & $15,29 \mathrm{a}$ & $0,06 \mathrm{ab}$ \\
$1 \%$ & $16,11 \mathrm{a}$ & $0,07 \mathrm{~b}$ \\
\hline Ekstrak kulit buah naga & & \\
\hline
\end{tabular}

Keterangan: Angka rata-rata yang ditandai dengan huruf yang sama pada kolom yang sama menunjukkan tidak berbeda nyata menurut Uji Jarak Berganda Duncan pada taraf $\alpha 0,05$.

Sementara itu, pemberian ekstrak kulit buah naga secara signifikan dapat mereduksi daya hantar listrik sebesar 15,5 \% serta meningkatkan bobot kering kecambah sebesar $40 \%$. Kondisi tersebut memberikan gambaran bahwa berbagai senyawa antioksidan non enzimatik yang terkandung dalam ekstrak kulit buah naga dapat menangkal atau meredam ROS (radikal bebas), oleh karenanya maka kerusakan membran sel dapat dicegah, kebocorannya berkurang sehingga daya hantar listriknya menjadi menurun. Komponen antioksidan non enzimatik tersebut terlibat dalam berbagai proses metabolisme di dalam sel dan berperan sebagai kofaktor enzim yang secara langsung mempengaruhi pertumbuhan dan perkembangan tanaman (Ahmad et al. 2019). Selain itu antioksidan juga dapat mencegah atau mereduksi gangguan pada proses sintesis sel sehingga pertumbuhan berjalan dengan baik serta akumulasi bahan kering makin bertambah. Dengan demikian secara keseluruhan ekstrak kulit buah naga potensial dapat digunakan untuk mitigasi dampak akibat cekaman salinitas pada fase perkecambahan benih kedelai.

\section{KESIMPULAN}

Hasil penelitian menunjukkan bahwa perlakuan cekaman salinitas mereduksi daya kecambah, laju perkecambahan, panjang akar, panjang epikotil, dan bobot kering kecambah, serta meningkatkan daya hantar listrik secara signifikan. Sebaliknya ekstrak kulit buah naga meningkatkan laju perkecambahan, panjang akar, dan mengurangi daya hantar listrik secara signifikan, serta dapat meningkatkan daya kecambah, panjang epikotil, dan bobot kering. Ekstrak kulit buah naga $2 \%$ berpotensi digunakan untuk mitigasi cekaman salinitas pada fase perkecambahan.

\section{DAFTAR PUSTAKA}

Ahmad R, Hussain S, Anjum MA, Khalid MF, Saqib M, Zakir I, Hassan A, Fahad S, Ahmad S. 2019. Oxidative Stress and Antioxidant Defense Mechanisms in Plants Under Salt Stress. In: Plant Abiotic Stress Tolerance. Cham: Springer International Publishing. p. 191-205.
Ahmed E, Salih AMB, Reem A. 2016. Alleviated effect of salinity stress by exogenous application of ascorbic acid on the antioxidant catalase enzymes and inorganic mineral nutrient elements contents on tomato plant. Int J Life Sci. 4:467-490.

Ansari O, Sharif-Zadeh F. 2012. Osmo and hydro priming improvement germination characteristics and enzyme activity of Mountain Rye (Secale montanum) seeds under drought stress. J Stress Physiol Biochem. 8(4):253-261.

Chinnusamy V, Jagendorf A, Zhu J-K. 2005. Understanding and Improving Salt Tolerance in Plants. Crop Sci. 45(2):437-448. doi:10.2135/cropsci2005.0437.

Denaxa N-K, Damvakaris T, Roussos PA. 2020. Antioxidant defense system in young olive plants against drought stress and mitigation of adverse effects through external application of alleviating products. Sci Hortic (Amsterdam). 259:1-11. doi:10.1016/j.scienta.2019.108812.

Fidrianny I, Ilham N, Hartati R. 2017. Antioxidant Profile and Phytochemical Content of Different Parts of Super Red Dragon Fruit (Hylocereus Costaricensis) Collected from West Java-Indonesia. Asian J Pharm Clin Res. 10(12):290-294. doi:10.22159/ajpcr.2017.v10i12.21571.

Handayani PA, Rahmawati A. 2012. Pemanfaatan Kulit Buah Naga (Dragon Fruit) sebagai Pewarna Alami Makanan Pengganti Pewarna Sintetis. J Bahan Alam Terbarukan. 1(2):19-24.

Ibrahim EA. 2016. Seed priming to alleviate salinity stress in germinating seeds. J Plant Physiol. 192:3846. doi:10.1016/j.jplph.2015.12.011.

Irianti T, Sugianto, Nuranto S, Kuswandi. 2017. Antioksidant. Yogyakarta: Universitas Gadjah Mada.

Jalgaonkar K, Mahawar MK, Bibwe B, Kannaujia P. 2020. Postharvest Profile, Processing and Waste Utilization of Dragon Fruit ( Hylocereus Spp .): A Review. Food Rev Int::1-27. doi:10.1080/87559129.2020.1742152.

Jungklang J. 2018. Effects of sodium chloride on germination, growth, relative water content, and chlorophyll, proline, malondialdehyde and vitamin $\mathrm{C}$ contents in Chinese white radish seedlings (Raphanus sativus L. Var. Iongipinnatus Bailey). Maejo Int J Sci Technol. 12(2):89-100.

Kementerian Pertanian. 2017. Statistik Pertanian. Susanti AA, Waryanto B, editors. Jakarta: Pusat Data dan Sistem Informasi Pertanian, Kementerian Pertanian Republik Indonesia. http://epublikasi.setjen.pertanian.go.id.

Kementerian Pertanian. 2018. Outlook Kedelai. In: Susanti AA, Waryanto B, editors. Outlook Tanaman Pangan dan Hortikultura. Pusat Data dan Sistem Informasi Pertanian, Sekretariat Jenderal Kementerian Pertanian. http://epublikasi.setjen.pertanian.go.id. 
Khan PSSV, Basha PO. 2015. Salt stress and leguminous crops. In: Legumes under Environmental Stress. Chichester, UK: John Wiley \& Sons, Ltd. p. 21-51.

Kristiono A, Purwaningrahayu RD, Taufiq A. 2018. Respons tanaman kedelai, kacang tanah, dan kacang hijau terhadap cekaman salinitas. Bul Palawija. 20:45-60.

Meloni DA, Oliva MA, Martinez CA, Cambraia J. 2003. Photosynthesis and activity of superoxide dismutase, peroxidase and glutathione reductase in cotton under salt stress. Environ Exp Bot. 49(1):69-76. doi:10.1016/S0098-8472(02)00058-8.

Nurliyana R, Syed Zahir I, Mustapha Suleiman K, Aisyah MR, Kamarul Rahim K. 2010. Antioxidant study of pulps and peels of dragon fruits: a comparative study. Int Food Res J. 17(2):367-375.

Purwaningrahayu RD, Taufiq A. 2017. Respon morfologi empat genotip kedelai terhadap cekaman salinitas. J Biol Indones. 13(2):175-188.

Putri NKM, Gunawan IWG, Suarsa IW. 2015. Aktivitas Antioksidan Antosianin dalam Ekstrak Etanol Kulit Buah Naga Super Merah (Hylocereus Costaricensis) dan Analisis Kadar Totalnya. J Kim (Journal Chem. 9(2):243-251.

Rachman A, Dariah A, Sutono S. 2018. Pengelolaan Sawah Salin Berkadar Garam Tinggi. Supriadi, Widiarta IN, editors. Jakarta: IAARD Press: Jakarta.

Rochmawati N. 2019. Pemanfaatan Kulit Buah Naga Merah (Hylocereus Polyrhizus) sebagai Tepung Untuk Pembuatan Cookies. J Pangan dan Agroindustri. 7(3):19-24.
Sayuti K, Yenrina R. 2015. Antioksidan alami dan sintetik. Padang: Andalas University Press.

Sekar M, Zulkifli NF, Azman NA, Azhar NAA, Norpi ASM, Musa HI, Sahak NS, Abdullah MS. 2016. Comparative antioxidant properties of methanolic extract of red and white dragon fruits. Int $\mathrm{J}$ Curr Pharm Res. 8(3):56-58.

Sharma P, Jha AB, Dubey RS, Pessarakli M. 2012. Reactive Oxygen Species, Oxidative Damage, and Antioxidative Defense Mechanism in Plants under Stressful Conditions. J Bot. 2012:1-26. doi:10.1155/2012/217037.

Sopandie D. 2013. Fisiologi Adaptasi Tanaman Terhadap Cekaman Abiotik Pada Agroekosistem Tropika. Bogor: Penerbit IPB Press.

Soundararajan P, Manivannan A, Jeong BR. 2019. Different Antioxidant Defense Systems in Halophytes and Glycophytes to Overcome Salinity Stress. In: Sabkha Ecosystems. Springer, Cham. p. 335-347.

Tabatabaei SA. 2013. Effect of salicylic acid and ascorbic acid on germination indexes and enzyme activity of sorghum seeds under drought stress. J Stress Physiol Biochem. 9(4):32-38.

Thirugnanasambandham K, Sivakumar V. 2017. Microwave assisted extraction process of betalain from dragon fruit and its antioxidant activities. J Saudi Soc Agric Sci. 16(1):41-48. doi:10.1016/j.jssas.2015.02.001.

Tsai Y, Lin C-G, Chen W-L, Huang Y-C, Chen C-Y, Huang K-F, Yang C-H. 2019. Evaluation of the Antioxidant and Wound-Healing Properties of Extracts from Different Parts of Hylocereus polyrhizus. Agronomy. 9(1):27. doi:10.3390/agronomy9010027. 